Community College Student Success Programs: A Synthesis, Critique, and Research Agenda

\author{
Gloria Crisp
}

The University of Texas-San Antonio

Amanda Taggart

Mississippi State University 


\begin{abstract}
A narrative review was developed to add to the discussion and dissemination of research on community colleges. The review adds to existing work by synthesizing and critiquing the empirical research to date specific to three of the most prevalent programmatic efforts presently seen on community college campuses: (a) learning communities, (b) student success courses, and (c) supplemental instruction. Empirical investigations or evaluations of student success programs from academic journals, conference presentations, dissertations, unpublished policy reports, and book chapters were identified, summarized, and critiqued. The review concludes with a proposed research agenda to advance research on program effectiveness at community colleges and implications for practice. Improving the academic success of community college students continues to be a compelling challenge for student affairs professionals, academic faculty, and policy makers (Bailey, Jenkins, \& Leinbach, 2007). Recent findings indicate that nearly threefourths of first-time students who begin their academic career at a four-year institution persist or are retained to the second year, compared to about $50 \%$ of first-time students who begin college at a community college (McIntosh \& Rouse, 2009). Moreover, findings consistently reveal that community college students are significantly less likely to persist or earn a college degree when compared to students who attend four-year schools (e.g., Dougherty, 1992; Dowd \& Melguizo, 2008; Nora, 1987; Wirt et al., 2004). For instance, data from the 1996/2001 Beginning Postsecondary Students Longitudinal Study indicate that although roughly $90 \%$ of community college students enroll with intentions of earning a credential or to transfer to a four-year university, a mere 39\% had earned a certificate, associate's degree, or bachelor's degree within six years (Hoachlander, Sikora, \& Horn, 2003). As such, parties have been actively engaged in
\end{abstract}


trying to understand the experiences and characteristics that contribute to community college student outcomes such as grades, academic integration, and decisions to persist.

Keywords: programs, student development, community college, learning community, supplemental instruction, student success course, orientation course, first-year experience 


\title{
Community College Student Success Programs: A Synthesis, Critique, and Research
}

\author{
Agenda \\ Research on community college students by Bailey and Alfonso (2005), Cohen and \\ Brawer (2008), and McIntosh and Rouse (2009) tell us that the experiences of community \\ college students are in many cases very different than students who attend four-year institutions. \\ Some of these differences include having limited opportunities to actively engage in social \\ activities, attending college part-time, working off-campus, having few opportunities to interact \\ with faculty and peers, and having limited academic preparation. Unfortunately, these \\ differences have also been empirically shown to contribute to the challenge of persisting and/or \\ successfully completing a college degree (e.g., Bers \& Smith, 1991; Brooks-Leonard, 1991; \\ Cohen \& Brawer, 2008; Feldman, 1993; Halpin, 1990; Mulligan \& Hennessy, 1990; Napoli \& \\ Wortman, 1998; Nora, 1987; Schmid \& Abell, 2003; Windham, 1994). \\ In turn, community college student affairs professionals and faculty continue to \\ implement a variety of student success programs and support services in an effort to help \\ students overcome the challenge to persist, earn a degree and/or transfer. These programmatic \\ efforts are largely supported by persistence theory (e.g., Astin's [1984, 1999] Student \\ Involvement Theory, Tinto's [1993] Model of Student Integration, Bean's [1985] Student \\ Attrition Model, Nora's [2004] Student/Institution Engagement Model). Efforts emphasize the \\ need to provide students with opportunities to become socially and academically integrated into \\ the college environment, connect with faculty and staff at the college, and/or overcome a \\ potential lack of cultural capital or academic preparedness (O'Gara, Karp, \& Hughes, 2008).


Among numerous programmatic efforts, three interventions are assumed by researchers (e.g., Tinto, Pascarella) and community college administrators alike to be particularly effective in influencing the success of community college students (as evidenced by the prevalence of programmatic efforts currently being implemented on community college campuses across the country). These practices exist in a variety of forms and include learning communities, student success courses, and supplemental instruction. Unfortunately, many of these programmatic efforts (at both the two- and four-year level) appear to exist in the absence of evidence supporting their net impact on student success. Rather, there is the tendency to assume that these programs are beneficial if they are rational and sound like they will benefit students, regardless of the corroborating evidence to support the existence of programs (Pascarella, 2006).

Of equal concern is the lack of synthesis, critique, and dissemination of research on community colleges (Bailey \& Alfonso, 2005). There is evidence to suggest that the context, or environment of the community college matters and that this context (e.g., prevalence of part-time faculty, lack of student involvement on campus, presence of continuing education and technical programs) may have a unique impact on student success (e.g., Pascarella, 1999; Pierson, Wolniak, Pascarella, \& Flowers, 2003). As such, there is a need for synthesis and critique of programmatic efforts that are conducted exclusively within a community college setting, as an absence of synthesis and critique makes it difficult for researchers interested in community college issues to find ways to contribute to the body of knowledge. In addition, the lack of synthesis and critique makes it difficult for student affairs professionals to easily and efficiently identify programmatic efforts that have been empirically shown to improve student success.

Several attempts have been made to synthesize the impact of student success programs, though few, if any, have offered both a synthesis and critique of programmatic efforts within a 
community college context. For instance, there have been several narrative reviews specific to learning communities (e.g., Andrade, 2007; Johnson, 2001; Killacky, Thomas, \& Accomando, 2002; Taylor, Moore, MacGregor, \& Lindblad, 2003). However, an ERIC review by Minkler (2002) is the only synthesis to date that has exclusively focused on learning communities at community colleges. It should be noted that while Minkler's work provides a concise summary of the most well known learning communities, there is a need to both update and add depth and critique his work. Similarly, although student success courses have existed for decades under various names and formats (e.g., orientation course, freshman success), there has been little attempt to synthesize and critique the work in this area. Furthermore, there is the need for review of the research done to date on supplemental instruction programs at community college campuses.

In turn, the following narrative review was conducted in Fall 2008 to add to the discussion and dissemination of research on community colleges. More specifically, this review adds to existing work by synthesizing and critiquing the empirical work to date that, based on the lead researcher's experience, are three of the most prevalent programmatic efforts presently seen on community college campuses: (a) learning communities, (b) supplemental instruction, and (c) student success courses. The review consists of five sections. First, an overview of each of the three programs is provided to give background information and context to the following sections. Second, the methodological and other criteria used for inclusion in the narrative review are explained. Third, the empirical studies for each of the program types are synthesized and critiqued. It has been recently suggested that a research agenda to evaluate the effectiveness of interventions specific to community college students would significantly advance the ability to improve student success (McIntosh \& Rouse, 2009). As such, the fourth section details a 
research agenda to advance research on program effectiveness at community colleges. Finally, because our intended audience is both academic researchers and community college administrators, we conclude with recommendations for practice.

\section{Description of Student Success Programs}

The following paragraphs provide a description of each of the three programs that were reviewed, synthesized, and critiqued, including a definition and summary of programmatic characteristics.

\section{Learning Communities}

Learning communities are typically defined as the enrollment of a cohort of students in a set of classes normally organized around a central theme (Taylor et al., 2003; Tinto, 1998; Weber, 2000). In doing so, students are provided opportunities to come to know each other, the course material, and the university more quickly and meaningfully than if they were enrolled separately in disconnected classes (Tinto, 1998). Common learning community models include paired or clustered courses, cohorts of students enrolled together in large courses, team-taught programs, and residence-based programs (Price, 2005).

Although learning communities may vary in content and structure, commonalities across programs include an integrated and interdisciplinary curriculum, crossing departments and divisions; a high level of participation and collaboration by faculty and students; an environment which supports new students in engaging in the life of an institution; and a student experience that establishes academic and social support networks (Brower \& Dettinger, 1998; Oertel, as cited in Taylor et al., 2003; Price, 2005). As of 2000, it was estimated that roughly $20 \%$ of community colleges in the United States implemented learning communities (Richburg-Hayes, Visher, \& Bloom, 2008), including the well-documented Opening Doors Learning Communities 
program that has been evaluated by MDRC using randomized experiments (Bloom \& Sommo, 2005; Richburg-Hayes et al., 2008; Scrivener, Bloom, LeBlanc, Paxson, \& Sommo, 2008).

\section{Student Success Courses}

In an effort to assess programmatic offerings, Cook (1996) administered a survey to 150 randomly selected public community colleges around the country. Survey results indicated that nearly all community colleges $(96 \%)$ had implemented some form of a student success course.

Student success courses, which through the years have been alternately identified as orientation courses and freshman year or success seminars, are characterized as programs aimed at assisting new entering students to transition to college (Cook, 1996). Programmatic goals are typically centered on providing information and assistance to students in the areas of study skills, learning styles, strategies for college success, educational and career planning and development, introduction to campus facilities, resources, services, and personal development such as health and/or well-being strategies (e.g., Derby, 2007; Derby \& Watson, 2006; Walls, 1996).

Student success programs vary between required and optional programs (Zimmerman, 2000) and credit and noncredit courses (Donnangelo \& Santa Rita, 1982). While they are most often offered for entering freshmen (Zimmerman, 2008), they are sometimes open to the entire college population (Walls, 1996). These courses also vary in length, ranging from 5-week programs (Zimmerman, 2000) to 10-week or semester-long courses that meet weekly or biweekly (Donnangelo \& Santa Rita, 1982; Glass \& Garrett, 1995). Programmatic support is offered to both community colleges and four-year institutions through the National Resource Center for the First Year Experience and Students in Transition (http://www.sc.edu/fye/).

\section{Supplemental Instruction}


The final student success program to be reviewed is supplemental instruction, which, similar to tutoring, involves a regularly scheduled peer-facilitated student assistance program that occurs outside of the classroom. The goal of supplemental instruction is to help students process course information, thereby improving test scores and course grades (Arendale, 1994). Supplemental instruction identifies "high-risk classes" (e.g., chemistry, calculus) rather than "'high-risk students", and is open to all students in the targeted class (Arendale, 1994).

Programmatic efforts for supplemental instruction at community colleges vary as to whether they are required (Marcus, Cobb, \& Shoenburg, 1996) or optional conditions of the courses to which they are attached (Zartisky \& Toce, 2006). Supplemental instruction programs also vary as to time and length, but they are regularly scheduled and led by either the instructor of the course (Maxwell, 1998) or by student leaders who have already completed the course in question. Students participating in supplemental instruction often work in small groups (Marcus et al., 1996).

\section{Method}

\section{Inclusion/Exclusion Criteria}

The following criteria were used to identify studies to be synthesized and critiqued. First, the included studies involved an empirical investigation or evaluation of learning communities, student success courses, or supplemental instruction. Existing narrative reviews, descriptions of programs in research/policy briefs or magazine-type publications, best practice articles, and conceptual or opinion pieces were used to frame the introduction and program descriptions but were not included in the research synthesis. Second, studies were all focused at the community college level. Third, included studies were specifically focused on an evaluation or empirical investigation of a learning community, student success course, or supplemental instruction 
program. Fourth, studies had to investigate the impact of the program on students. Studies that focused on other populations such as faculty members were excluded. Fifth, included studies did not have to be published. However, included studies were publicly available or archived in Fall 2008.

\section{Search Procedures}

Within the above mentioned parameters, journal articles, conference presentations, dissertations, unpublished policy reports, and book chapters were located through a comprehensive search of publicly available literature through October of 2008. Electronic searches were performed via the following databases: Education Full Text, ERIC via EBSCO, JSTOR, and Project Muse. Next, manual searches were performed in 39 journals including higher education journals and those specific to community colleges, evaluation, and/or student affairs (e.g., Journal of College Student Development, Journal of the Freshman Year Experience, Community College Review). Search terms included different combinations of the following terms: “"programs," “student development," “community college," “'learning community," “'supplemental instruction," “'student success course,", “orientation course," "'first-year experience,', and "student success.',

Due to shortage of published empirical studies, this research reviewed books and unpublished manuscripts from policy centers and organizations focused on student success among community college students. Sixteen books specific to higher education and student affairs (e.g., How college affects students) were searched for possible inclusions. Websites from 27 organizations and centers that were known to focus efforts and/or conduct research on student success were also searched (see Table 1 for a complete list of organizations/websites). Finally, 
the reference lists of existing narrative reviews, empirical studies, and relevant books were reviewed for possible inclusions.

[Insert Table 1 here]

\section{Summary and Critique of Research Studies}

It should be noted that our original intent was to perform a meta-analysis of three of the most prominent programmatic efforts currently implemented at community colleges.

Unfortunately, our initial search revealed a limited number of studies that both manipulated an independent variable and utilized a control group. We were also unable to identify comparable study outcomes (i.e., effect sizes, means, standard deviations) for an adequate number of identified studies. However, our initial search did identify a considerable number studies to be synthesized and critiqued for each of the program types.

In turn, our summary and critique are framed around the following study characteristics: (a) research methodology; (b) study outcomes; (c) program operational definition; (d) main findings/conclusions; (e) methodological strengths; and (f) methodological weaknesses. The researchers independently read each study selected for inclusion and coded the study characteristics in a database. Discrepancies were discussed until agreement was reached among the coders. Table 2 provides a summary of the study outcomes for each of the reviewed studies. It should be noted that a few studies focused on more than one program and, thus, are included in multiple sections.

[Insert Table 2 here]

\section{Results}

The following section provides a synthesis and critique of studies centered on learning communities, student success courses, and supplemental instruction at the community college 
level. Of the literature reviewed, 16 articles discussed learning communities, 15 articles focused on student success courses, and five studies investigated the impact of supplemental instruction.

\section{Learning Communities}

Quantitative research on the effectiveness of learning communities in community colleges has focused on the impact of learning communities on academic outcomes such as retention/persistence (e.g., Richburg-Hayes et al., 2008; Scrivener et al., 2008); course grades and grade point average (e.g., Goldberg \& Finkelstein, 2002; Raftery, 2005); course completion (e.g., Bloom \& Sommo, 2005; Moore, 2000); the degree to which students are socially and/or academically integrated (e.g., Engstrom \& Tinto, 2007; Tinto, 1997); and the influence of learning communities on student or faculty perceptions (e.g., Minkler, 2000).

Similarly, several studies have included a qualitative component to better understand the specific ways in which learning communities support students' academic success (Engstrom \& Tinto, 2007; Tinto, 2007; Tinto \& Love, 1995). Although the majority of reviewed studies investigated the impact of learning communities on community college students as a whole, several studies focused on remedial or developmental students (e.g., Richburg-Hayes et al., 2008); and one study investigated the effects of learning communities on students enrolled in technical or vocational programs (Goldberg \& Finkelstein, 2002).

Overall, research findings indicate that learning communities have a positive impact or are positively related to student retention, grades, course completion rates, social and academic integration, and/or faculty/student perceptions. For example, Raftery (2005) found that class attendance, course completion, and retention rates increased for students participating in a learning communities program entitled Academic Improvement for Success that enrolled a cohort of students in two or more academic and personal or career development courses. 
Similarly, findings of a randomized control group design from the Opening Doors Project at Kingsborough Community College indicate that assignment to the learning community group significantly improved a number of student outcomes. Improvements included students' sense of integration and belonging and the number of courses attempted and completed (Scrivener et. al, 2008).

However, out of the 16 studies that we reviewed, four failed to find that learning communities have a positive impact on student retention and/or grade point averages (i.e., Goldberg \& Finkelstein, 2002; Minkler, 2000; Moore, 2000; Richburg-Hayes et al., 2008). For instance, findings by Goldberg and Finkelstein (2002) failed to identify a significant difference in semester-to-semester retention, course grades, and GPA between students enrolled and not enrolled in learning communities. As previously mentioned, the study by Goldberg and Finkelstein (2002) included students enrolled in technical or vocational programs. Therefore, although replication is warranted, findings suggest that learning communities may have less of an effect on technical students' persistence decisions, course grades, and GPA. It is less clear why learning communities were not found to significantly improve semester-to-semester retention rates and/or grades in studies by Minkler (2000), Moore (2000), and Richburg-Hayes et al. (2008). Institutional differences in how learning communities were conceptualized, measured, or implemented are hypothesized to explain these differences.

Qualitative findings by Hodge, Lewis, Kramer, and Hughes (2001) revealed that the atmosphere of learning communities promoted access and interaction with faculty and other students. Similarly, Tinto (1997) and Tinto and Love (1995) found that participating in learning communities allowed students to develop a network of supportive peers which, in turn, facilitated their integration and transition to college. In addition, findings indicated that learning 
communities provided students with a richer intellectual experience. More specifically, the continuity of class assignments and activities helped students engage in their own thinking about cross-disciplinary topics. In addition, the learning community courses were perceived by participants as allowing for more practical life experiences, resulting in higher levels of participation and in-depth discussions (Tinto, 1997).

\section{Student Success Courses}

Twelve of the 15 studies focused on student success courses investigated the impact of the course on some measure of student retention/persistence. Of these, all but one quantitative study found success courses to be positively related to student retention. The exception was Derby and Watson (2005), who limited their analysis to Hispanic students. In contrast, findings with regard to the impact of student success courses on students' grades or GPA have been mixed. Although five of the reviewed studies indicated a positive relationship between success courses and grades (i.e., Belcher, Ingold, \& Lombard, 1987; Donnangelo \& Santa Rita, 1982; Glass \& Garrett, 1995; Raymond \& Napoli, 1998; Stovall, 1999), three failed to find a significant positive relationship between the variables (i.e., Grunder \& Hellmich, 1996; Robles, 2002; Walls, 1996). It should be noted that Grunder and Hellmich (1996) found significant differences for African American students and males, but not White and female students. The impact or relationship between student success courses and course completion is even less clear as findings from two studies indicated a positive relationship (i.e., Derby \& Watson, 2006; Stovall, 1999) and two did not (i.e., Grunder \& Hellmich, 1996; Walls, 1996). Similarly, while some studies have found student success courses to be positively related to graduation or earning a degree (i.e., Derby \& Smith, 2004; Raymond \& Napoli, 1998; Stovall, 1999; Zimmerman, 
2000), findings by Derby and Watson $(2005,2006)$, which focused on Hispanic and African American students, did not identify a significant relationship.

In contrast to several of the learning community studies that have used rigorous experimental or non-experimental designs, the large majority of student success course studies have been fraught with numerous methodological and measurement issues (e.g., selection bias, lack of control of extraneous or confounding variables, using qualitative methods to assess outcomes such as persistence). These issues (which are discussed in more detail in the section below) likely contribute to the inconsistency in results, and in many cases such issues potentially limit the internal validity_ or ability of the researchers to draw correct inferences from the data about the population - of the results.

Quantitative studies that involve research designs that control for confounding variables are, therefore, worthy of mention. One of these is the study by Zeidenberg, Jenkins, and Calcagno (2007) who used logistic regression to compare the odds of three outcomes for students who completed a Student Life Skills (SLS) student success course with those students who did not complete the course. Controlling for student characteristics, test scores, and taking developmental courses, findings indicated that students who completed SLS courses were more likely than students who did not complete the course to attain one of the following three indicators of success: (a) earning a community college credential, (b) transferring to the state university system, and (c) remaining enrolled in college after five years. These achievements also held true among students who needed at least one developmental course and for students who were required to take developmental courses in all three subject areas.

With exception of recent work by O'Gara et al. (2008) and mixed methods dissertations by Robles (2002) and Walls (1996), the reviewed studies focused on student success courses 
have exclusively used quantitative methods. Most notably, the study by O'Gara et al. (2008) explored the ways in which student success courses impact student outcomes using interview data. Similar to Tinto and colleagues' work with learning communities, the researchers found that student success courses may act as a catalyst for forming relationships with other students and faculty, which in turn may help students integrate themselves academically and socially. Moreover, participants revealed that student success courses may help students develop study skills, learn about the college, and obtain advice about courses.

\section{Supplemental Instruction}

Although we only located five studies (all of which were quantitative) that have explored the relationship or effect of participating in supplemental instruction and student outcomes, the findings have been overwhelmingly positive. More specifically, our review revealed that supplemental instruction has been shown to be positively related to student retention, grades, and course completion or success. Moreover, findings by Maxwell (1998) indicate that supplemental instruction may have a positive impact on peer relations. However, it is noteworthy that the ability of the researchers to draw meaningful and useful inferences of all of the supplemental instruction studies may be limited due to selection bias or an absence of experimental designs. With the exception of Maxwell's (1998) work, the validity of quantitative findings may also be influenced by a lack of control of extraneous variables.

\section{Conclusions}

In conclusion, our review reveals that more work is needed specific to understanding impact of interventions on community college students. We appear to have a descriptive understanding of the characteristics of each of these student success programs as well as evidence to suggest that each of these programs are related to student success. However, we have 
less empirical evidence that demonstrates best practices or how to effectively implement these programs on a community college campus. We will know more about the long-term impacts of learning communities when additional findings from the Opening Doors (i.e., Bloom \& Sommo, 2005; Richburg-Hayes et al., 2008; Scrivener et al., 2008) and Pathways to College Success Projects (Engstrom \& Tinto, 2007) are published in a few years. However, we currently have little if any evidence to suggest that there is a cause and effect relationship between student success courses and supplemental instruction on any student outcomes. Moreover, we have research findings that suggest that there is variance in how learning communities and student success courses impact different groups of students (e.g., Derby \& Watson, 2005, 2006; Goldberg \& Finkelstein, 2002), but we know little about the factors influencing these differences.

\section{Critique of the Current Literature}

Across the literature, we noted several strengths and weaknesses in studies of the three types of community college student success programs. We were pleased to identify examples of high quality work being done specific to community college students. For instance, our review identified examples of rigorous experimental designs focused on examining the long-term effects of learning communities (i.e., Bloom \& Sommo, 2005; Richburg-Hayes et al., 2008; Scrivener et al., 2008). These studies detail differences between experimental and control groups, controlling for selection bias through random assignment, and using effect sizes to assess practical significance in the findings.

Similarly, Tinto and colleagues have conducted some excellent longitudinal, mixed method studies that add to our understanding of the specific ways in which learning communities support students' academic success (i.e., Engstrom \& Tinto, 1997, 2007; Tinto \& Love, 1995). 
Also, with regard to student success courses, Zeidenberg et al. (2007) provide a well-designed non-experimental study that controlled for student characteristics, exam scores, and enrolling in developmental coursework. Furthermore, O'Gara et al. (2008) provide rigorous qualitative work that contributes to our understanding of how and why student success courses are beneficial for students.

Among the weaknesses of the articles we reviewed, many of the studies were published in ERIC or unpublished dissertations rather than in peer reviewed, empirical journals. Expanding our search provided a more comprehensive review. However, we acknowledge that including a diversity of publications also increased the variation in the quality of the existing literature to be reviewed. Moreover, our criteria led us to identify numerous examples of program description (e.g., Bennin, 1999; Gaspar, 2002; Trautmann \& Boes, 2000) or reflective practice (HamonsBryner \& Robinson, 1994), which contributed little to our understanding of how programs impact student outcomes. Second, we observed a lack of statistical control in many of the nonexperimental studies (i.e., lack of control built into research design) that would allow for a more complex understanding of the relationship among variables (e.g., Hodge, Lewis, Kramer \& Hughes, 2001; Raftery, 2005; Trautmann \& Boes, 2000; Walls, 1996; Wolfe, 1991; Zimmerman, 2000).

Third, much of the qualitative or mixed method work to date has not been designed to be consistent with Creswell's (2008) qualitative strategies of inquiry and methods of analysis and interpretation. For instance, we saw little evidence of inductive data analysis which involves building themes, patterns, and categories from the data (e.g., Hamons-Bryner \& Robinson, 1994; Hodge, Lewis, Kramer \& Hughes, 2001). Rather, with the exception of work by Tinto (1997), Tinto and Love (1995), and O'Gara et al. (2008), the qualitative literature with regard to student 
success programs has been used as a supplement or form of triangulation to the quantitative data, which contributes little to our understanding of the specific ways in which programs impact students.

Fourth, there were often substantial differences in how programs were operationally defined and subsequently implemented and measured across studies. In some cases, there was little if any description of the program (e.g., Raymond \& Napoli, 1998); in others there was large variance in the design and/or measurement of the program. For instance, the student success course in Zimmerman's (2000) study had journal writing as a central component of the fiveweek course, while the program studied by Derby and Smith (2004) centered on familiarizing students with college resources and services and developing an academic plan. Although we understand that programs are often designed specifically for the student population at a particular institution, the inconsistency in programmatic design and goals made it difficult to compare findings across studies.

A fifth concern, which was more evident among the student success and supplemental instruction studies, was the prevalence of selection bias (e.g., Grunder \& Hellmich, 1996; Stovall, 1999; Walls, 1996; Marcus et al., 1996; Maxwell, 1998). Due to the limited use of experimental designs and practicality of allowing students to self-select into programs, in more cases than not it was unclear whether the difference in the outcome was due to the program or to some difference between the treatment and control groups. Finally, most program effectiveness research to date has been limited to findings from a single institution, and it has often utilized small samples that are not representative of the student population. This limits the external validity, or generalizability, of the results (Bailey \& Alfonso, 2005). These single institution 
studies are not sufficient to drive programmatic decisions or policy (Richburg-Hayes et al., 2008).

\section{Proposed Research Agenda}

In response to our critique of the current literature, we offer several recommendations to advance the literature. First, there is a need for research that allows us to measure a "causal" relationship between programs and student outcomes (Bailey \& Alfonso, 2005; McIntosh \& Rouse, 2009; O'Gara et al., 2008; Pascarella, 2006). Although there is a wealth of research on the effectiveness of student success programs at four-year institutions (e.g., Engberg \& Mayhew, 2007; Ogden, Thompson, Russell, \& Simons, 2003; Pike, 1999; Stassen, 2003), it is incorrect to assume the effects will be the same for community college students (Pascarella, 2006). As such, we recommend that academic researchers who study student success courses and supplemental instruction strongly consider utilizing random assignment (which controls for selection bias). This will identify causal effects of programmatic interventions for community college students. We also challenge researchers to be mindful of designing interventions that expose the participants to more than one treatment (e.g., simultaneous participation in a learning community and mentoring program). This will avoid the threat of multiple treatment interference.

When the manipulation of the independent variable (i.e., program) is not possible, researchers should utilize non-experimental methods that include longitudinal designs and statistical controls that consider precollege effects (Pascarella, 2006). As previously mentioned, the majority of non-experimental quantitative work has been limited to descriptive findings that do not control for extraneous variables (e.g., Hodge, Lewis, Kramer, \& Hughes, 2001). However, the use of more rigorous designs, such as Ordinary Least Squares (OLS) and logistic regression, structural equation modeling or multilevel modeling techniques, would substantially add to our 
understanding of the impact that programs have on student success among community college students.

Similarly, we concur with researchers who argue that learning communities, student success courses, and supplemental instruction programs should be incorporated into persistence theory/models (i.e., Raymond \& Napoli, 1998; Richburg-Hayes et al., 2008). More specifically, we recommend that the work of Tinto (1997) and others be continued to examine the indirect and direct influence of programs within the context of the other factors (e.g., academic integration, financial concerns, family support) that have been shown to influence the persistence decisions of community college students.

Beyond identifying causal and non-causal relationships, there is a need to understand why interventions have a particular impact on students (Pascarella, 2006). Our review reveals that the majority of work to date has been quantitative. As such, we recommend that qualitative work, like that of Tinto and Love (1995) and O'Gara et al. (2008) be conducted to add to our understanding of how and why various programs are related to student outcomes. Research is needed to determine exactly what part or experiences of these programs are related to student success for students (House \& Kuchynka, 1997; Zeidenberg et al., 2007). This is especially true for supplemental instruction research that has been limited to quantitative work. Furthermore, we challenge researchers (both qualitative and quantitative) to engage in work that considers how programmatic efforts impact different groups of students such as men and women, different ethnic groups, and students who are classified as nontraditional or first generation college students.

In light of findings by Richburg-Hayes et al. (2008) that indicate the long-term effects of learning communities might be different than the short-term, there is a need to examine the long- 
term effects of learning communities. Moreover, we recommend that researchers expand the work of Ogden et al. (2003) by investigating the long-term impacts of supplemental instruction on various student outcomes. Similarly, the literature with regard to student success courses would be enhanced by an examination of long-term programmatic effects. Future research should also continue to move beyond the use of small, narrow samples and examine the extent to which findings are externally valid and can be generalized to broad student populations. As a final note, replication is currently the exception rather than the rule. Credibility of evidence would be enhanced by an emphasis on purposeful replication of findings (Pascarella, 2006).

\section{Implications for Practice}

The present review demonstrates a need for empirical research that is directly tied to policy and programmatic interventions. There seem to be increasing opportunities for practitioners to conduct research through grant funded projects such as Achieving the Dream that allow community colleges the opportunity to implement and evaluate learning community, student success, and supplemental instruction programs. Moreover, we believe there is the potential of adding survey items into institutional surveys that ask students to identify whether they participated in learning communities, supplemental instruction, or student success courses. This would allow practitioners the ability to compare student outcomes among students who do and do not participate in programmatic efforts. It would also control for the other variables that have been shown to impact student success.

Similarly, there is a need to connect existing research to practice, as "research will have a fundamental influence on the colleges only when it plays a more prominent role on the campuses"' (Bailey \& Alfonso, 2005, p. 3). Unfortunately, a large number of studies on program effectiveness at the community college are not published, available online, or easily accessible to 
the student affairs and research communities. We recognize that student affairs professionals and community college faculty are engaged in this type of work and in many cases presenting findings at local and state conferences. As such, we encourage those who engage in program evaluation to submit their work to the mainstream journals. As with so many issues in education, this particular challenge requires collaboration among researchers and practitioners in order to(a) understand the unique characteristics, attitudes, and behaviors that are related to academic success and, (b) effectively apply this knowledge to the development and implementation of student success programs/interventions. As such, we also encourage collaboration between and within community college districts as well as between academic researchers and practitioners. 


\section{References}

Andrade, M. S. (2007). Learning communities: Examining positive outcomes. Journal of College Student Retention: Research, Theory \& Practice, 9(1), 1-20.

Arendale, D. R. (1994). Understanding the supplemental instruction model. New Directions for Teaching and Learning, 60, 11-21.

Astin, A. W. (1984). Student involvement: A developmental theory for higher education. Journal of College Student Development, 25(4), 297-308.

Astin, A. W. (1999). Student involvement: A developmental theory for higher education. Journal of College Student Development, 40(5), 518-529.

Bailey, T. R., \& Alfonso, M. (2005). Paths to persistence: An analysis of research on program effectiveness at community colleges. Lumina Foundation for Education New Agenda Series, 6(1), 1-44. Indianapolis, IN: Lumina Foundation for Education.

Bailey, T., Jenkins, D., \& Leinbach, D. T. (2007). The effect of student goals on community college performance measures. Community College Research Center Brief, 33, 1-4.

Bean, J. B. (1985). Interaction effects based on class level in an explanatory model of college dropout syndrome. American Educational Research Journal, 22, 35-64.

Belcher, M. J., Ingold, S., \& Lombard, M. (1987). Addressing retention through an orientation course: Results from a North Campus study (Research Report No. 87-24). Miami, FL: Miami-Dade Community College, Florida Office of Institutional Research. (ERIC Document Reproduction Service No. ED296761)

Bennin, H. E. (1999). Our lives in community: A learning pilot project for at-risk students. Paper presented at the NISOD International Conference on Teaching and Leadership Excellence, Austin, TX. (ERIC Document Reproduction Service No. ED433063) 
Bers, T. H., \& Smith, K. E. (1991). Persistence of community college students: The influence of student intent and academic and social integration. Research in Higher Education, 32(5), $539-556$.

Bloom, D., \& Sommo, C. (2005). Building learning communities: Early results from the Opening Doors demonstration at Kingsborough Community College. New York, NY: MDRC.

Brooks-Leonard, L. C. (1991). Demographic and academic factors associated with first to second term retention in a two year college. Community/Junior College, 15, 57-69.

Brower, A. M., \& Dettinger, K. M. (1998). What is a learning community? Toward a comprehensive model. About Campus, November-December, 15-21.

Cohen, A. M., \& Brawer, F. B. (2008). The American community college (5th ed.). San Francisco, CA: Jossey-Bass.

Cook, L.P. (1996). A description of new student orientation programs at two-year colleges in the United States. Dissertation Abstracts International. (UMI No. 9619361)

Creswell, J. W. (2008). Research design: Qualitative, quantitative, and mixed methods approaches (3rd ed.). Upper Saddle River, NJ: Sage.

Crisp, G. (2008, May). Mentoring students at Hispanic serving institutions: Validation of a theoretical framework. Presented at the Annual Forum of the Association for Institutional Research, Seattle, WA.

Derby, D. C. (2007). Predicting degree completion: Examining the interaction between orientation course participation and ethnic background. Community College Journal of Research and Practice, 31(11), 883-894. 
Derby, D. C., \& Smith, T. (2004). An orientation course and community college retention. Community College of Research and Practice, 28, 763-773.

Derby, D. C., \& Watson, L. W. (2005). Community college retention of Hispanic students: The study of an orientation course. The Journal of College Orientation and Transition, 13(1), $52-61$.

Derby, D. C., \& Watson, L. W. (2006). African-American retention within a community college: Differences in orientation course enrollment. Journal of College Student Retention, 8(3), $377-390$.

Donnangelo, F. P., \& Santa Rita, E. D. (1982). The effects of two collage orientation courses upon the academic performance and retention of entering freshmen. New York, NY: Bronx Community College. (ERIC Document Reproduction Service No. ED232747)

Dougherty, K. J. (1992). Community colleges and baccalaureate attainment. Journal of Higher Education, 63(2), 188-214.

Dowd, A. C., \& Melguizo, T. (2008). Socioeconomic stratification of community college transfer access in the 1980's and 1990's: Evidence from HS\&B and NELS. The Review of Higher Education, 31(4), 377-400.

Engberg, M. E., \& Mayhew, M. J. (2007). The influence of first-year "success" courses on student learning and democratic outcomes. Journal of College Student Development, 49(2), 95-109.

Engstrom, C., \& Tinto, V. (2007). Learning communities for academically under-prepared students. Pathways to College Success Project. Syracuse NY: Syracuse University.

Feldman, M. J. (1993). Factors associated with one-year retention in a community college. Research in Higher Education, 34(4), 503-512. 
Gaspar, R. F. (2002). Hillsborough Community College campus developmental learning community program 2001-2002. (ERIC Document Reproduction Service No. ED466841)

Glass, J. C. Jr., \& Garrent, M. S. (1995). Student participation in a college orientation course, retention, and grade point average. Community College Journal of Research and Practice, 19(2), 117-132.

Goldberg, B., \& Finkelstein, M. (2002). Effects of a first-semester learning community on nontraditional technical students. Innovative Higher Education, 26(4), 235-249.

Grunder, P. G., \& Hellmich, D. M. (1996). Academic persistence and achievement of remedial students in a community college's College Success program. Community College Review, 24(2), 21-33.

Halpin, R. L. (1990). An application of the Tinto model to the analysis of freshman persistence in a community college. Community College Review, 17(4), 22-32.

Hammons-Bryner, S., \& Robinson, B. (1994). Excitement in core curriculum classes. College Teaching, 42(3), 97-100.

Hoachlander, G., Sikora, A. C., \& Horn, L. (2003). Community college students: Goals, academic preparation, and outcomes. Education Statistics Quarterly, 5(2), 121-128.

Hodge, G., Lewis, T., Kramer, K., \& Hughes, R. (2001). Collaboration for excellence: Engaged scholarship at Collin County Community College. Community College Journal of Research and Practice, 25, 625-690.

House, J. D., \& Kuchynka, S. J. (1997). The effects of a freshmen orientation course on the achievement of health science students. Journal of College Student Development, 38(5), $540-542$. 
Johnson, J. L. (2001). Learning communities and special efforts in the retention of university students: What works, what doesn't and is the return worth the investment? Journal of College Student Retention, 2(3), 219-238.

Killacky, J., Thomas, C., \& Accomando, A. (2002). Learning communities and community colleges: A case study. Community College Journal of Research and Practice, 26, 763775.

Marcus, D., Cobb, E. B., \& Shoenberg, R. E. (1996). Lessons learned from FIPSE Projects IIIJune 1996-Anne Arundel Community College: Fund for the improvement of postsecondary education. Washington, DC: U.S. Department of Education.

Maxwell, W. E. (1998). Supplemental instruction, learning communities, and students studying together. Community College Review, 26(2), 1-18.

McIntosh, M. F., \& Rouse, C. E. (2009). The other college: Retention and completion rates among two-year college students. Washington, DC: Center for American Progress.

Minkler, J. E. (2000). The efficacy of learning communities at two community colleges (Doctoral dissertation). University of Idaho, Moscow, ID. (ERIC Document Reproduction Service No. ED457918)

Minkler, J. E. (2002). ERIC review: Learning communities at the community college. Community College Review, 30(13), 46-63.

Moore, L. H. (2000). A mixed-method approach to evaluating learning communities for underprepared community college students: The integrated studies communities at Parkland College (Doctoral dissertation). University of Illinois at Urbana-Champaign. (ERIC Document Reproduction Service No. ED457936) 
Mulligan, S. C., \& Hennessy, J. J. (1990, April). Persistence in a community college: Testing attrition models. Paper presented at the annual meeting of the American Educational Research Association, Boston, MA.

Napoli, A. R., \& Wortman, P. M. (1998). Psychosocial factors related to retention and early departure of two-year community college students. Research in Higher Education, 39(4), $419-455$.

Nora, A. (1987). Determinants of retention among Chicano college students. Research in Higher Education, 26(1), 31-59.

Nora, A. (2004). Access to higher education for Hispanic students: Real or illusory? In J. Castellanos \& L. Jones' (Eds.), The majority in the minority: Expanding the representation of Latina/o faculty, administrators and students in higher education (pp. 47-68). New York, NY: Stylus.

O’Gara, L., Karp, M. M., \& Hughes, K. L. (2008, September). Student success courses in the community college: An exploratory study of student perspectives (CCRC Brief). New York, NY: Community College Research Center.

Ogden, P., Thompson, D., Russell, A., \& Simons, C. (2003). Supplemental instruction: Shortand long-term impact. Journal of Supplemental Instruction, 26(3), 2-8.

Pascarella, E. T. (1999). New studies track community college effects on students. Community College Journal, 69, 9-14.

Pascarella, E. T. (2006). How college affects students: Ten directions for future research. Journal of College Student Development, 47(5), 508-520. 
Pierson, C. T., Wolniak, G. C., Pascarella, E. T., \& Flowers, L. A. (2003). Impacts of two-year and four-year college attendance on learning orientation. Review of Higher Education, 26(3), 299-321.

Pike, G. (1999). The effects of residential learning communities and traditional residential living arrangements on educational gains during the first year of college. Journal of College Student Development, 40(3), 269-284.

Price, D. V. (2005, December). Learning communities and student success in postsecondary education (A background paper). New York, NY: MDRC Press.

Raftery, S. (2005). Developmental learning communities at Metropolitan Community College. New Directions for Community Colleges, 129(Spring), 23-72.

Raymond, L., \& Napoli, A. R. (1998). An examination of the impact of a freshman seminar course on student academic outcomes. Journal of Applied Research in the Community College, 6(1), 27-34.

Richburg-Hayes, L., Visher, M. G., \& Bloom, D. (2008). Do learning communities affect academic outcomes? Evidence from an experiment in a community college. Journal of Research on Educational Effectiveness, 1(1), 33-65.

Robles, S. Y. (2002). The influence of a freshman orientation course on the academic performance and retention of new community college students (Doctoral dissertation). Stockton, CA: University of the Pacific. (ERIC Document Reproduction Service No. ED479876)

Schmid, C., \& Abell, P. (2003). Demographic risk factors, study patterns, and campus involvement as related to student success among Guilford Technical Community College Students. Community College Review, 31(1), 1-16. 
Scrivener, S., Bloom, D., LeBlanc, A., Paxson, C. E., \& Sommo, C. (2008). A good start: Twoyear effects of a freshmen learning community program at Kingsborough Community College. New York, NY: MDRC.

Stassen, M. L. A. (2003). Student outcomes: The impact of varying living-learning community models. Research in Higher Education, 44(5), 581-613.

Stovall, M. L. (1999). Relationships between participation in a community college student success course and academic performance and persistence (Unpublished doctoral dissertation). University of Illinois, Urbana-Champaign.

Taylor, K., Moore, W. S., MacGregor, J., Lindblad, J. (2003). What we know now. National Learning Communities Project Monograph Series. Washington, DC: The Washington Center for Improving the Quality of Undergraduate Education at The Evergreen State College in cooperation with the American Association for Higher Education.

Tinto, V. (1993). Leaving college: Rethinking the causes and cures of student attrition. Chicago, IL: University of Chicago Press.

Tinto, V. (1997). Classrooms as communities: Exploring the educational character of student persistence. The Journal of Higher Education, 68(6), 599-623.

Tinto, V. (1998, January). Learning communities and the reconstruction of remedial education in higher education. Paper presented at the Conference on Replacing Remediation in Higher Education at Stanford University, sponsored by the Ford Foundation at the United States Department of Education.

Tinto, V., Love, A. G. (1995). A longitudinal study of learning communities at LaGuardia Community College. University Park, PA: National Center on Postsecondary Teaching, Learning, and Assessment. (ERIC Document Reproduction Service No. ED380178) 
Trautmann, N., \& Boes, C. (2000). Sociology, writing, and reading in the community college learning community: The stills/content tango principles of sociology and freshman English and critical reading and principles of sociology. (ERIC Document Reproduction Service No. ED454897)

Walls, G. D. (1996). An evaluation of an orientation to college course in a community college setting. Dissertation Abstracts International. (UMI No. 9702710)

Weber, J. (2000). Learning communities in higher education: A field observation case study (Doctoral dissertation). Widener University, Chester, PA. (ERIC Document Reproduction Service No. ED459882)

Windham, P. (1994, August). The relative importance of selected factors to attrition at public community colleges. Paper presented at the 23rd Annual Conference of the Southeastern Association for Community Colleges, Savannah, GA.

Wirt, J., Choy, S., Rooney, P., Provasnik, S., Sen, A., \& Tobin, R. (2004). The condition of education 2004 (NCES 2004-077). U.S. Department of Education, National Center for Education Statistics. Washington, DC: U.S. Government Printing Office.

Wolfe, R. (1991). Supplemental instruction with mentoring support at Anne Arundel Community College. Fund for the Improvement of Postsecondary Education. (ERIC Document Reproduction Service No. ED413942)

Zaritsky, J. (1994, May). Supplemental instruction: A peer tutoring program at LaGuardia Community College. Paper presented at the Annual Conference of the Community College General Education Association, Albany, NY (ERIC Document Reproduction Service No. ED373850) 
Zaritsky, J. S., \& Toce, A. (2006). Supplemental instruction at a community college: The four pillars. New Directions for Teaching and Learning, 106, 23-31.

Zeidenberg, M., Jenkins, D., \& Calcagno, J. C. (2007, June). Do student success courses actually help community college students succeed? (Brief No. 36). New York, NY: Community College Research Center.

Zimmerman, A. (2000). A journal-based orientation course as a predictor of student success at a public two-year technical college. Journal of the First-Year Experience, 12(1), 29-43.

*Asterisk denotes reference included in narrative review. 


\title{
Table 1
}

\section{Reviewed Organizations/Centers}

\author{
Achieving the Dream (http://www.achievingthedream.org/default.tp) \\ American Counseling Association (http://www.counseling.org/) \\ American Council on Education (http://www.acenet.edu/AM/) \\ American Diploma Project (http://www.achieve.org/ADPNetwork) \\ American Association of Community Colleges \\ (http://www2.aacc.nche.edu/research/index.htm) Center for Research on Developmental \\ Education and Urban Literacy (CRDEUL) (http://www.cehd.umn.edu/ CRDEUL/) \\ Center for Student Success-California Community Colleges (http://css.rpgroup.org/) \\ Center for the Study of College Student Retention (http://www.cscsr.org/) \\ Civil Rights Project (http://www.civilrightsproject.ucla.edu/) \\ Community College Research Center (CCRC) (http://ccrc.tc.columbia.edu/) \\ Council for Opportunity in Education (http://www.coenet.us/) \\ Council for the Advancement of Standards (https://www.cas.edu/index.html) \\ Education Commission of the States (http://www.ecs.org/) \\ Educational Policy Institute (http://www.educationalpolicy.org/) \\ Institute for Higher Education Policy (IHEP) (http://www.ihep.org/) \\ Lumina Foundation for Education (http://www.luminafoundation.org/) MDRC \\ (http://www.mdrc.org/) \\ National Academic Advising Association (http://www.nacada.ksu.edu/) \\ National Coalition Building Institute (http://ncbi.org/) \\ National Center for Postsecondary Improvement (http://www.stanford.edu/group/ncpi/) \\ National Center for Public Policy and Higher Education (NCPPHE) \\ (http://www.highereducation.org/) \\ National Resource Center for the Freshmen Year Experience (http://www.sc.edu/fye/) \\ Pathways to College Network (http://www.pathwaystocollege.net/) \\ Policy Center on the First Year of College (http://www.brevard.edu/Default.aspx?tabid=652) \\ The Puente Project (http://www.puente.net/) \\ State Policy Inventory Database Online (http://www2.wiche.edu/spido) \\ Student Affairs Administrators in Higher Education (NASPA) (http://www.naspa.org/) \\ U.S. Department of Education (http://www.ed.gov/index.jhtml)
}


Table 2

Study Outcomes - Learning Communities, Student Success Courses, and Supplemental Instruction

\begin{tabular}{|c|c|c|c|c|c|c|c|}
\hline & $\begin{array}{c}\text { Retention } \\
\text { or } \\
\text { persistence }\end{array}$ & $\begin{array}{c}\text { Grades or } \\
\text { GPA }\end{array}$ & $\begin{array}{c}\text { Course } \\
\text { completion } \\
\text { or success }\end{array}$ & $\begin{array}{c}\text { Social or } \\
\text { academic } \\
\text { integration }\end{array}$ & $\begin{array}{c}\text { Student } \\
\text { perceptions }\end{array}$ & $\begin{array}{c}\text { Faculty } \\
\text { perceptions }\end{array}$ & Other \\
\hline \multicolumn{8}{|l|}{ Learning communities } \\
\hline \multicolumn{8}{|l|}{ Bennin (1999) } \\
\hline Bloom \& Sommo (2005) & & & $\mathrm{X}$ & & & & $\mathrm{X}$ \\
\hline Engstrom \& Tinto (2007) & & & & $\mathrm{X}$ & $\mathrm{X}$ & & \\
\hline Gaspar (2002) & $\mathrm{X}$ & $\mathrm{X}$ & & & & & $\mathrm{X}$ \\
\hline Goldberg \& Finkelstein (2002) & $\mathrm{X}$ & $\mathrm{X}$ & & $\mathrm{X}$ & & & \\
\hline Hamons-Bryner \& Robinson (1994) & & & & & $\mathrm{X}$ & & \\
\hline Hodge, Lewis, Kramer, \& Hughes (2001) & $\mathrm{X}$ & & & & & $\mathrm{X}$ & $\mathrm{X}$ \\
\hline Minkler (2000) & $\mathrm{X}$ & $\mathrm{X}$ & & & $\mathrm{X}$ & $\mathrm{X}$ & \\
\hline Moore $(2000)$ & & $\mathrm{X}$ & $\mathrm{X}$ & & & & \\
\hline Raftery (2005) & $\mathrm{X}$ & $\mathrm{X}$ & $\mathrm{X}$ & & $\mathrm{X}$ & & $\mathrm{X}$ \\
\hline Richburg-Hayes, Visher, \& Bloom (2008) & $\mathrm{X}$ & $\mathrm{X}$ & $\mathrm{X}$ & & & & $\mathrm{X}$ \\
\hline Scrivener et al. (2008) & $\mathrm{X}$ & $\mathrm{X}$ & & $\mathrm{X}$ & $\mathrm{X}$ & & \\
\hline Tinto (1997) & $\mathrm{X}$ & & & $\mathrm{X}$ & $\mathrm{X}$ & & \\
\hline Tinto \& Love (1995) & $\mathrm{X}$ & $\mathrm{X}$ & $\mathrm{X}$ & & $\mathrm{X}$ & & \\
\hline Trautman \& Boes (2000) & $\mathrm{X}$ & $\mathrm{X}$ & & & & $\mathrm{X}$ & \\
\hline Weber $(2000)$ & & & & & $\mathrm{X}$ & $\mathrm{X}$ & \\
\hline \multicolumn{8}{|l|}{ Student success courses } \\
\hline Belcher (1987) & $\mathrm{X}$ & $\mathrm{X}$ & & & & & \\
\hline Derby \& Smith (2004) & $\mathrm{X}$ & & & & & & $\mathrm{X}$ \\
\hline Derby \& Watson (2005) & $\mathrm{X}$ & & & & & & $\mathrm{X}$ \\
\hline Derby \& Watson (2006) & $\mathrm{X}$ & & $\mathrm{X}$ & & & & $\mathrm{X}$ \\
\hline Derby (2007) & & & & & & & $\mathrm{X}$ \\
\hline Donnangelo \& Santa Rita (1982) & $\mathrm{X}$ & $\mathrm{X}$ & & & & & \\
\hline Glass \& Garrett (1995) & $\mathrm{X}$ & $\mathrm{X}$ & & & & & \\
\hline Grunder \& Hellimich (1996) & & $\mathrm{X}$ & $\mathrm{X}$ & & & & \\
\hline O’Gara, Karp, \& Hughes (2008) & & & & & $\mathrm{X}$ & & \\
\hline Raymond \& Napoli (1998) & $\mathrm{X}$ & $\mathrm{X}$ & & & & & $\mathrm{X}$ \\
\hline Robles (2002) & $\mathrm{X}$ & $\mathrm{X}$ & & & & & \\
\hline Stovall (1999) & $\mathrm{X}$ & $\mathrm{X}$ & $\mathrm{X}$ & & & & $\mathrm{X}$ \\
\hline Walls (1996) & $\mathrm{X}$ & $\mathrm{X}$ & $\mathrm{X}$ & & $\mathrm{X}$ & & $\mathrm{X}$ \\
\hline
\end{tabular}




\begin{tabular}{|l|c|c|c|c|c|c|}
\hline Zeidenberg, Jenkins, \& Calcagno (2007) & X & & & & & X \\
\hline Zimmerman (2000) & X & & & & & X \\
\hline Supplemental instruction & & & & & & \\
\hline Marcus, Cobb, \& Shoenburg (1996) & X & X & X & & & \\
\hline Maxwell (1998) & & & & & & \\
\hline Wolfe (1991) & X & X & X & & & \\
\hline Zaritsky \& Toce (2006) & & X & X & & & \\
\hline Zaritsky (1994) & & X & & & \\
\hline
\end{tabular}

